Bull. Chem. Soc. Ethiop. 2021, 35(3), 471-484.

ISSN 1011-3924

(C) 2021 Chemical Society of Ethiopia and The Authors

Printed in Ethiopia

DOI: https://dx.doi.org/10.4314/bcse.v35i3.1

Online ISSN 1726-801X

\title{
MINERAL CONTENTS OF BARLEY GRAINS AND ITS PROCESSED FOODS (KOLO, PORRIDGE, BREAD AND INJERA) CONSUMED IN ETHIOPIA
}

\author{
Zewdie Tilahun, Bhagwan Singh Chandravanshi* and Mesfin Redi-Abshiro
}

Department of Chemistry, College of Natural and Computational Sciences, Addis Ababa University, P.O. Box 1176, Addis Ababa, Ethiopia

(Received September 29, 2021; Revised December 26, 2021; Accepted December 26, 2021)

\begin{abstract}
Barley (Hordeum vulgare L.) is one of the most widely cultivated stable food crops in the world. Barley grain samples were collected from four selected areas (Bahir Dar, Bure, Finote Selam and Debre Markos) of Ethiopia and four types of processed food (kolo, porridge, bread and injera) were prepared from it. The levels of essential and non-essential metals in barley grains and its processed food were determined by microwave plasmaatomic emission spectrometry after wet digestion with a mixture of $\mathrm{HNO}_{3}$ and $\mathrm{HClO}_{4}(5: 1$, v/v). The concentration $(\mathrm{mg} / \mathrm{kg}$ dry weight) in the barley grains were in the ranges $\mathrm{K}$ (5482-6516), Mg (546-643), Ca (445-684), Mn (7.319.80), Fe (127-439), $\mathrm{Cu}(0.88-1.86), \mathrm{Zn}$ (42.8-56.8), Pb (0.39-2.73), Cd (3.01-4.66). The concentrations of all the metals in the four types of processed barley foods showed variation among each other. The results indicate that Ethiopian barley grains and its processed foods are good source of essential metals.
\end{abstract}

KEY WORDS: Barley, Hordeum vulgare L., Processed foods, Macro-minerals, Micro-minerals, Toxic metals

\section{INTRODUCTION}

Cereals are common food crops of the world. They provide food calories and proteins to human. They are staple foods for most of the population. Barley (Hordeum vulgare L.) is a cereal crop. It belongs to the tribe Triticeae of family Poaceae. It is an important cereal crop and cultivated over broad environmental conditions in the world [1-3]. It ranks fourth in the world in production after wheat, maize and rice [4].

Barley is used commercially for animal feed, to produce malt, and for human food applications as it is rich in protein, carbohydrates, dietary fibers, minerals, vitamins and antioxidants $[5,6]$. Barley is also an important crop in Ethiopia [3]. It is ranked fifth among the cereals on the basis of area of cultivation while third on the basis of production per unit area in Ethiopia. It covers $7.56 \%$ of the land under grain crop cultivation with a yield of 1.96 tones/ha [7].

Ethiopia is second largest producer of barley in Africa next to Morocco, accounting for about $26 \%$ of the total barley production in the continent $[8,9]$. It serves as a component of various foods. It is used in soups and stews, and the grain is used locally in bread, biscuits, and the traditional beremeal bannock. Barley is used commercially for animal feed, to manufacture malt, which is primarily used in beer production, and for human food applications [10, 11]. It is used for the preparation of Ethiopian fermented bread injera, porridge, roasted snack, and in homemade beer. Barley provides basic necessities of life (food, feed, and beverages) for many people in the Ethiopian highlands [2]. Barley is used in the preparation of different recipes in Ethiopia. It is deep rooted in the culture of people's diets. It has also been used for the preparation of various types of traditional foods such as kolo (roasted grains), kita (fried bread), dabo (baked bread), beso (snack), genfo (porridge), chuko (barley conserved with butter), tihlo (dough balls), shorba (soup), kinche (cooked broken grains), and injera (pan cake bread) in Ethiopia [12, 13].

Barley grain consists of about $65-68 \%$ starch, $10-17 \%$ protein, $2-3 \%$ free lipids, $4-9 \% \beta$ glucans and $1.5-2.5 \%$ minerals. Total dietary fiber ranges from $11-34 \%$ containing soluble dietary

*Corresponding author. E-mail: bscv2006@yahoo.com

This work is licensed under the Creative Commons Attribution 4.0 International License 
fiber within $3-20 \%$ [14]. Barley grain also contains important minerals such as zinc (up to 50 $\mathrm{mg} / \mathrm{kg}$ ), iron (up to $60 \mathrm{mg} / \mathrm{kg}$ ) and soluble fibers. It also contains higher amounts of vitamins A and $\mathrm{E}$ than the other cereals [2].

Chemical composition and physical characteristics of cereal grains used in human and livestock feeding have been reported in many studies [15]. Variations in the chemical composition and physical characteristics of cereal grains results from changes in the environmental factors, such as rainfall, temperature, soil conditions, fertilization and genetic factors $[16,17]$. The characterization of variations in nutritional values of cereal grains that result from environmental factors and soil properties may help for improving the quality of cereal grains [17].

Minerals are considered to be essential in human nutrition and that they are important constituents of bones, teeth, tissues, muscles, blood, and nerve cells. Generally, the minerals help in the maintenance of acid-base balance, the response of nerves to physiological stimulation, blood clotting, structural, physiological, catalytic, and regulatory [18]. Minerals may be broadly classified as macro (major), micro (minor), or trace and toxic [19]. The macro-minerals required in amounts of 100 milligrams or more per day include calcium, magnesium, phosphorus, sodium, sulfur, and chloride. Micro-elements or trace elements are present at low levels in the body or required in smaller amounts in the diet, including iron, copper, cobalt, dine, zinc, manganese, molybdenum, fluoride, chromium and selenium. The micro-minerals are required in amounts less than 100 milligrams per day [19]. Toxic elements such as mercury, arsenic, cadmium, and lead, can diminish mental and central nervous system function; cause damage to blood composition as well as the kidneys, lungs, and liver; and reduce energy levels [20].

Some studies have been conducted on the levels of minerals in the raw and processed foods in Ethiopia. Atlabachew and Chandravanshi [21] determined the metal contents in commercially available enset food products (kocho and bulla). Debebe et al. [22] studied the metal contents in enset corm. Aregahegn et al. [23] reported the metal contents in tubers and flour of Dioscorea abyssinica. Akalu and Chandravanshi [24] determined the selected metals in raw and processed Lupinus albus L. Ayele et al. [25] studied the mineral content and antinutritional factors of yam and taro during cooking. Abebe and Chandravanshi [26] and Abebe et al. [27] reported the metal contents of raw maize and its processed food. Tegegne et al. [28] studied the mineral contents of raw and cooked rice. However, no systematic study has been done of barley grain and its processed food in Ethiopia.

Therefore, it is worthwhile to assess the nutritional value of barley and its food products in different geographic locations having different environmental conditions. Hence, this study is aimed to investigate the mineral compositions of barely grain and its processed foods. Previously published studies have reported higher contents of calcium, iron and zinc in barely than other common cereals $[12,13,29]$. However, mineral contents in the barely flours is variable and controversial in the literature $[12,13,29]$. The data on mineral contents in barely grains and its processed foods are scarce and limited. Therefore, the aim of present investigation is to determine the amount of minerals in barely flours and barely processed foods by microwave plasma-atomic emission spectrometry.

\section{EXPERIMENTAL}

Apparatus and equipment

Ceramic mortar and pestle was used to ground barley samples. Electronic series balance (OPTECH, A205EC, Italy) with precision of $\pm 0.0001 \mathrm{~g}$ was used for weighing samples. A Kjeldahl (UK) digestion block was used for the digestion of barley samples. Microwave plasmaatomic emission spectrometer (Agilent 4200, MP-AES, USA) was used for quantification of metals. 


\section{Chemicals}

Analytical grade reagents and chemicals were used in the study. A 69.5\% $\mathrm{HNO}_{3}$ (Scharlau Chemie S.A. European Union, Spain) and $70 \% \mathrm{HClO}_{4}$ (BDH Laboratory Supplies AnalaR ${ }^{\circledR}$, Poole, England) were used for digestion of barely samples. Stock standard solutions containing 1000 $\mathrm{mg} / \mathrm{L}$ of the metals $\mathrm{K}, \mathrm{Mg}, \mathrm{Ca}, \mathrm{Mn}, \mathrm{Fe}, \mathrm{Cu}, \mathrm{Zn}, \mathrm{Cd}$ and $\mathrm{Pb}$ (BDH Chemicals Ltd Spectrosol ${ }^{\circledR}$, Poole, England) were used for preparation of calibration standards and for the spiking experiments. Deionized water was used throughout the study.

\section{Description of the study area}

The study was conducted in four locations (Bahir Dar, Bure, Finote Selam and Debre Markos). Bahir Dar is situated on the southern shore of Lake Tana, the source of Blue Nile River. It is about $549 \mathrm{~km}$ northwest of Addis Ababa at an altitude of 1801 masl, having latitude of $11038 \mathrm{~N}$ and longitude of 37010 "E. It is the most heavily populated belt of the Ethiopian plateau. Its area is about 16,000 hectares [30]. Bure is located about $150 \mathrm{~km}$ South West of Bahir Dar with longitude and latitude of $10^{\circ} 42^{\prime} \mathrm{N}$ and $37^{\circ} 4^{\prime} \mathrm{E}$. Its annual rainfall ranges from 1386 to $1757 \mathrm{~mm}$ [31]. Finote Selam is located in the West Gojjam Zone of the Amhara Region. It has longitude and latitude of $10^{\circ} 42^{\prime} \mathrm{N}, 37^{\circ} 16^{\prime} \mathrm{E}, 10.7^{\circ} \mathrm{N}, 37.267^{\circ} \mathrm{E}$, with an elevation of 1917 masl [32]. Debre Markos is located in the north west of Addis Ababa at a distance of $298 \mathrm{~km}$. Its area is $6,160 \mathrm{ha}$. Its average annual temperature is $18.5^{\circ} \mathrm{C}$; mean annual rainfall is $1,380 \mathrm{~mm}$ [33]. The geographical descriptions of sample collection sites are summarized in Table 1.

Table 1. Geographical descriptions of sample collection sites.

\begin{tabular}{|c|l|c|c|c|c|}
\hline S. No. & Sample site & \multicolumn{4}{|c|}{ Approximate geographical locations } \\
\cline { 3 - 6 } & & Latitude & Longitude & $\begin{array}{c}\text { Altitude above } \\
\text { sea level }(\mathrm{m})\end{array}$ & $\begin{array}{c}\text { Distance from } \\
\text { Addis Ababa }(\mathrm{km})\end{array}$ \\
\hline 1 & Debre Markos & $10^{\circ} 20^{\prime} \mathrm{N}$ & $37^{\circ} 43^{\prime} \mathrm{E}$ & 2446 & 298 \\
\hline 2 & Fenote-Selam & $10^{\circ} 42^{\prime} \mathrm{N}$ & $37^{\circ} 16^{\prime} \mathrm{E}$ & 1957 & 388 \\
\hline 3 & Bure & $10^{\circ} 42^{\prime} \mathrm{N}$ & $37^{\circ} 4^{\prime} \mathrm{E}$ & 2091 & 400 \\
\hline 4 & Bahir Dar & $11^{\circ} 36^{\prime} \mathrm{N}$ & $37^{\circ} 23^{\prime} \mathrm{E}$ & 1800 & 549 \\
\hline
\end{tabular}

Sample collection

Barley samples were collected from Bahir Dar, Bure, Fenote-Selam and Debre Markos. About $0.5 \mathrm{~kg}$ of samples was collected from three farmers in the open markets separately from each sampling site. The samples from the three farmers from each site were mixed to get about $1.5 \mathrm{~kg}$ composite sample from each site, packed in the polyethylene plastic bags and were brought to Addis Ababa for analysis.

\section{Description of processed foods from barely}

In Ethiopia, barley is a dependable source of food in the highlands areas. Its grain is used for the preparation of different foodstuffs, such as kolo, porridge, bread and injera, and local drinks, such as tella, borde and beer [9]. This study is concerned on four types of barley foods such as kolo, porridge, bread and injera.

Kolo is a dehulled, well-roasted barley whole grain that is eaten as a snack, alone or mixed with roasted seeds such as ground nut, chick pea, sunflower or safflower seeds. Kolo is commonly eaten both at home and at various social gatherings, such as after funerals ceremonies, during many official meetings or during traveling. Kolo is also eaten by people having gastritis problems [34]. 
Porridge

Porridge is widely eaten breakfast foods in Ethiopia. It is most commonly consumed during a special celebration such as birthdays and weddings. Traditionally, in many parts of Ethiopia, there is a common practice to prepare barley porridge for an expectant mother. A postnatal mother eats porridge with spiced butter for breakfast and her guests are also served porridge. Traditionally porridge is also considered as a supplementary food for children aged between 6 months and 24 months to make the baby grow faster and stay healthy [12].

\section{Bread}

Bread is the most widely eaten food. It has desirability to all population rich and poor, rural and urban. It is a good source of nutrients, such as macronutrients (carbohydrates, protein and fat) and micronutrients (minerals and vitamins) that are all essential for human health. The widespread consumption of bread in the world has necessitated the study of the composition of the bread to improve its nutritive value [35].

\section{Injera}

Injera is a fermented, pancake-like soft, circular flat bread with small bubbly structures or eyes (honey-comb-like holes) on its top surface, which are produced due to the production and escape of $\mathrm{CO}_{2}$ during fermentation and baking, respectively. It is prepared from various cereals depending on availability such as teff, barley, sorghum, maize, wheat and rice or a combination of some of these cereals [3].

\section{Sample preparation for metal determination}

Samples were washed with tap water to remove the adsorbed soil and other particulate matters and the barley grains were placed in the hot water for $10 \mathrm{~min}$. The clean grains were crushed in the traditional mortar to remove kernel and dried in the air. The dried grains were separated from the kernel by winnowing and rinsed with deionized water. The samples were exposed to sunlight in open air for drying.

A $200 \mathrm{~g}$ portion of the dried barley grains were ground using electronic blending device and stored in sample bottles. The flour was used to prepare porridge, bread and Injera.

A $200 \mathrm{~g}$ barley grain samples were roasted using metal pans, cooled and ground using the electronic blending device. The roasted grain is called "kolo" in Ethiopia. The powdered kolo sample was stored sample bottles.

The porridge was prepared according to Ethiopian traditional procedure. A $200 \mathrm{~g}$ barley flour was added to the $100 \mathrm{~mL}$ of boiling distilled water and homogenized with wooden spoon for 5$10 \mathrm{~min}$. The prepared porridge was put in to oven at $200{ }^{\circ} \mathrm{C}$ for $3 \mathrm{~h}$ to complete dryness. The dried porridge sample was ground to powder and stored sample bottle.

The bread was prepared according to the traditional procedure used in Ethiopia. A $200 \mathrm{~g}$ barley flour and $0.5 \mathrm{~g}$ starter (yeast) was mixed well with $200 \mathrm{~mL}$ distilled water and after $1 \mathrm{~h}$ the dough was fermented. The metal pan was heated and the dough was placed on the pan. The pan was covered with lid, and after 10 min the bread was inverted upside down for uniform heating. The bread was taken off from the pan and allowed to cool. It was cut in to pieces and exposed to oven at $150{ }^{\circ} \mathrm{C}$ for $3 \mathrm{~h}$ to complete dryness until a constant weight was obtained. The dried bread sample was crushed in to powder form and stored in the sample bottle.

Injera was made by mixing $200 \mathrm{~g}$ barley flour with $200 \mathrm{~mL}$ distilled water to make a dough, and triggering a fermentation process by inoculating the dough with yeast, a starter culture, left over from a previous fermentation. The fermentation lasted 3 days, then $200 \mathrm{~mL}$ boiled distilled 
water was added after which the dough was thinned into a batter before baking on an open platter. A clay plate was heated and the dough was placed on the plate. The plate was covered with lid, and after 5 min the injera was taken off from the plate and allowed to cool. The injera was cut in to pieces and exposed to oven at $150{ }^{\circ} \mathrm{C}$ for $3 \mathrm{~h}$ to complete dryness. The dried injera sample was crushed in to powder form and stored in the sample bottle.

It should be noted that traditionally the heated metal pan is used for preparing bread and kolo. Therefore, the heated metal pan was used for preparing bread and kolo in the present study. Normally contamination occurs when liquid sample is in contact with the metal pan. However, the contamination will be negligible when a solid sample is in contact with the metal. Therefore, we expect negligible contamination of metals from the metal pan during preparation of bread and kolo.

\section{Optimization of digestion procedure}

Wet acid digestion is one of the methods commonly used for samples of organic matrix. It is based on changing digestion parameters like temperature, volume ratio of reagent and time. Kjeldahl apparatus is one of the wet acid digestion apparatus by which organic component are assumed to be decomposed in the form of different gases leaving metallic elements in the residue. Several trials for the optimization of digestion procedure for sample preparation were made as shown in Table 2 .

Table 2. Optimization of reagent volume, temperature and time for digestion of $0.5 \mathrm{~g}$ of barley sample.

\begin{tabular}{|c|c|c|c|l|l|}
\hline $\begin{array}{c}\text { Sample } \\
\text { No. }\end{array}$ & $\begin{array}{c}\text { Total volume } \\
(\mathrm{mL})\end{array}$ & $\begin{array}{c}\text { Optimized volume ratio } \\
(\mathrm{mL})\left(\mathrm{HNO}_{3}: \mathrm{HClO}_{4}\right)\end{array}$ & $\begin{array}{c}\text { Temp. } \\
\left({ }^{\circ} \mathrm{C}\right)\end{array}$ & Time $(\mathrm{h})$ & Observation \\
\hline 1 & 6 & $3: 3$ & 240 & $4: 00$ & Colorless solution \\
\hline 2 & 6 & $4: 2$ & 240 & $4: 00$ & Colorless solution \\
\hline $\mathbf{3}$ & $\mathbf{6}$ & $5: 1$ & $\mathbf{2 4 0}$ & $\mathbf{4 : 0 0}$ & Clear colorless solution \\
\hline 4 & 8 & $3: 2$ & 240 & $4: 00$ & Colorless solution \\
\hline 5 & 5 & $4: 1$ & 240 & $4: 00$ & Colorless solution \\
\hline 6 & 5 & $5: 2$ & 240 & $4: 00$ & Colorless solution \\
\hline 7 & 7 & $6: 3$ & 240 & $4: 00$ & Light yellow solution \\
\hline 8 & 9 & $5: 1$ & 240 & $4: 00$ & Colorless solution \\
\hline 1 & 6 & $5: 1$ & 150 & $4: 00$ & Light yellow solution \\
\hline 2 & 6 & $5: 1$ & 180 & $4: 00$ & Light yellow solution \\
\hline 3 & 6 & $5: 1$ & 210 & $4: 00$ & Colorless solution \\
\hline 4 & 6 & $\mathbf{5 : 1}$ & 240 & $4: 00$ & Colorless solution \\
\hline $\mathbf{5}$ & $\mathbf{6}$ & $5: 1$ & 300 & $4: 00$ & Light yellow solution \\
\hline 6 & 6 & $5: 1$ & 270 & $1: 30$ & Light yellow solution \\
\hline 1 & 6 & $5: 1$ & 270 & $2: 00$ & Light yellow solution \\
\hline 2 & 6 & $5: 1$ & 270 & $2: 30$ & Colorless solution \\
\hline 3 & 6 & $5: 1$ & 270 & $3: 00$ & Colorless solution \\
\hline 4 & 6 & $5: 1$ & $\mathbf{2 7 0}$ & $\mathbf{4 : 0 0}$ & Clear colorless solution \\
\hline 5 & 6 & $\mathbf{5 : 1}$ & & \\
\hline $\mathbf{6}$ & $\mathbf{6}$ & & & \\
\hline
\end{tabular}

The bold font indicates the optimum condition.

\section{Digestion of samples}

A $0.5 \mathrm{~g}$ barley grain flour from the prepared sample were transferred to a $250 \mathrm{~mL}$ round bottom

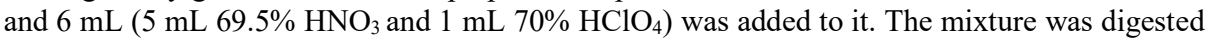
on a Kjeldhal digestion block for the optimized period of $4 \mathrm{~h}$ at the optimized temperature 270

${ }^{\circ} \mathrm{C}$. After $4 \mathrm{~h}$ of the digestion time the digested mixture was cooled to room temperature for about 
$30 \mathrm{~min}$ without removing the condenser. After removing the condenser about $10 \mathrm{~mL}$ distilled water was added to the solution by rinsing the neck of the round bottom flask and the tip of the condenser which was in contact with the flask to dissolve the precipitate formed on cooling and to reduce dissolution of filter paper by digest residue during filtration using Whatman filter paper in to $50 \mathrm{~mL}$ volumetric flask. The solution was diluted to $50 \mathrm{~mL}$ with deionized water.

A $0.5 \mathrm{~g}$ of the four types of processed foods from barley were also digested separately in the same manner as the barley grains.

\section{Instrument calibration}

MP-AES was calibrated using four series of working standards for each metal of inters. The working standard solution of each metal was prepared by diluting the standard solutions. Concentrations of the working standards, correlation coefficients of the calibration curves for each metal are listed in Table 3. From the correlation coefficients in Table 3 for each metal it is possible to conclude that the change in the emission intensity with concentration is in good positive correlation and are linearly fit.

\section{Method detection and quantification limits}

The method detection limit (MDL) and method quantification limit (MQL) were determined as three and ten times the standard deviation of blank solutions, respectively [36]. The results are given in Table 4 which clearly indicated that the studied metals can be determined at trace levels in the barley grain and its processed foods.

Table 3. The wavelength, correlation coefficient and equation of the calibration curves for determination of metals using MP-AES.

\begin{tabular}{|c|c|c|c|c|}
\hline Metals & $\begin{array}{c}\text { Wavelength } \\
(\mathrm{nm})\end{array}$ & $\begin{array}{c}\text { Concentration of working } \\
\text { standards }(\mathrm{mg} / \mathrm{L})\end{array}$ & $\begin{array}{c}\text { Correlation } \\
\text { coefficient }\left(\mathrm{R}^{2}\right)\end{array}$ & $\begin{array}{c}\text { Equation for } \\
\text { calibration curves }\end{array}$ \\
\hline $\mathrm{K}$ & 766.491 & $0,5,10,15,20$ & $\mathrm{R}^{2}=0.9999$ & $\mathrm{I}=25338 \mathrm{C}-4.9378$ \\
\hline $\mathrm{Mg}$ & 285.213 & $0,5,10,15,20$ & $\mathrm{R}^{2}=0.9999$ & $\mathrm{I}=105108 \mathrm{C}+14221$ \\
\hline $\mathrm{Ca}$ & 422.673 & $0,5,10,15,20$ & $\mathrm{R}^{2}=0.9984$ & $\mathrm{I}=85968 \mathrm{C}+30355$ \\
\hline $\mathrm{Mn}$ & 403.076 & $0,5,10,15,20$ & $\mathrm{R}^{2}=0.9999$ & $\mathrm{I}=27657 \mathrm{C}-0.0332$ \\
\hline $\mathrm{Fe}$ & 371.993 & $0,5,10,15,20$ & $\mathrm{R}^{2}=0.9999$ & $\mathrm{I}=5056.6 \mathrm{C}-0.5136$ \\
\hline $\mathrm{Cu}$ & 324.754 & $0,5,10,15,20$ & $\mathrm{R}^{2}=0.9999$ & $\mathrm{I}=106700 \mathrm{C}+2.83$ \\
\hline $\mathrm{Zn}$ & 213.857 & $0,5,10,15,20$ & $\mathrm{R}^{2}=0.9999$ & $\mathrm{I}=5270.3 \mathrm{C}-0.0354$ \\
\hline $\mathrm{Pb}$ & 405.781 & $0,5,10,15,20$ & $\mathrm{R}^{2}=0.9999$ & $\mathrm{I}=2926.7 \mathrm{C}-0.0692$ \\
\hline $\mathrm{Cd}$ & 228.802 & $0,5,10,15,20$ & $\mathrm{R}^{2}=0.9998$ & $\mathrm{I}=7851.3 \mathrm{C}+919.77$ \\
\hline
\end{tabular}

$\mathrm{I}=$ emission intensity, $\mathrm{C}=$ concentration.

Table 4. Instrument method detection limits for the analysis of barley sample by MP-AES.

\begin{tabular}{|l|l|l|l|l|l|l|l|l|l|}
\hline Metals & $\mathrm{K}$ & $\mathrm{Mg}$ & $\mathrm{Ca}$ & $\mathrm{Mn}$ & $\mathrm{Fe}$ & $\mathrm{Cu}$ & $\mathrm{Zn}$ & $\mathrm{Pb}$ & $\mathrm{Cd}$ \\
\hline MDL$(\mathrm{mg} / \mathrm{g})$ & 0.1 & 0.6 & 0.5 & 0.01 & 0.05 & 0.03 & 0.06 & 0.006 & 0.006 \\
\hline MQL(mg/g) & 0.3 & 1.9 & 1.8 & 0.02 & 0.1 & 0.05 & 0.2 & 0.02 & 0.02 \\
\hline
\end{tabular}

Validation of optimized procedure

Spiking experiments were used to validate the optimized procedure. The samples were spiked with known concentration of each metal and digested and analyzed in similar conditions using 
optimized procedure for sample analysis. The percentage recoveries were obtained within the range $93.4-107 \%$ which is within the acceptable range for all metals.

\section{Statistical analysis}

The statistical software (SPSS Version 22) was used for the analysis of variance (ANOVA) and Pearson correlation. The graphical expression was done using Microsoft Excel 7 in addition to data analysis.

\section{RESULTS AND DISCUSSION}

\section{Levels of metals}

Each sample was analyzed in triplicate. The mean values were determined from the results of triplicate analysis of each sample for each metal and the results are reported in terms of mean values \pm SD (Table 5 and 6).

Table 5. Metals concentration in barley grain samples from four different areas of Ethiopia.

\begin{tabular}{|c|c|c|c|c|}
\hline \multirow{2}{*}{ Metal } & \multicolumn{4}{|c|}{ Metal concentration (mean \pm SD) } \\
\cline { 2 - 5 } & Bahir Dar & Bure & Fenote Selam & Debre Markos \\
\hline $\mathrm{K}$ & $6516 \pm 0.5$ & $6156 \pm 0.8$ & $6110 \pm 0.4$ & $5482 \pm 0.3$ \\
\hline $\mathrm{Mg}$ & $643 \pm 0.4$ & $554 \pm 0.3$ & $546 \pm 0.3$ & $551 \pm 0.8$ \\
\hline $\mathrm{Ca}$ & $357 \pm 0.86$ & $363 \pm 0.4$ & $445 \pm 0.86$ & $684 \pm 0.9$ \\
\hline $\mathrm{Mn}$ & $7.63 \pm 0.3$ & $7.31 \pm 0.3$ & $9.42 \pm 0.6$ & $9.8 \pm 0.9$ \\
\hline $\mathrm{Fe}$ & $213 \pm 0.6$ & $127 \pm 0.6$ & $439 \pm 0.3$ & $128 \pm 0.6$ \\
\hline $\mathrm{Cu}$ & $1.86 \pm 0.1$ & $0.88 \pm 0.1$ & $1.15 \pm 0.1$ & $0.97 \pm 0.1$ \\
\hline $\mathrm{Zn}$ & $56.8 \pm 0.3$ & $42.8 \pm 0.3$ & $46.7 \pm 0.3$ & $45.3 \pm 0.9$ \\
\hline $\mathrm{Pb}$ & $2.73 \pm 0.2$ & $0.39 \pm 0.05$ & $0.98 \pm 0.1$ & $0.87 \pm 0.1$ \\
\hline $\mathrm{Cd}$ & $4.66 \pm 0.1$ & $3.75 \pm 0.2$ & $3.51 \pm 0.1$ & $3.01 \pm 0.1$ \\
\hline
\end{tabular}

Distribution of metals in barley grain sample

The plants uptake metals by different and complex biochemical processes. The accumulation of metals depends on the ability of particular plant to absorb metals from the soil and the availability of the minerals in the soluble forms in the particular areas. The variation in the level of metals in soil depends on the degree of pollution of the biosphere from the rapid industrialization and modern large scale agricultural activities [34-36]. The use of sewage sludge, pesticides, herbicides and fertilizers on agricultural lands highly affect the quality of food products for humans and animals. The distribution and accumulation of metals in barely grain are the reflections of the mineral composition of the soil and the degree of mineral pollution of the environment in which the barely plant grows. The metal concentrations of barley grain vary considerably at different locations due to differences in composition of chemicals and fertilizers and also due to variation in the soil composition and climatic conditions [34-36].

\section{Levels macro essential metals in barley grains}

There was a wide variation in the level of macro-essential metals among the samples from the four different sites (Table 5). K content was at the highest level among all the major metals. Its content was also at the highest level among all the metals determined in this study. It was within the range $5482-6516 \mathrm{mg} / \mathrm{kg}$, followed by $\mathrm{Ca}(445-684)$ and $\mathrm{Mg}(546-643) \mathrm{mg} / \mathrm{kg}$. Thus order of macro-essential metals in barely grain was $\mathrm{K}>\mathrm{Ca}>\mathrm{Mg}$. Among the sample sites the highest concentration $(\mathrm{mg} / \mathrm{kg})$ of $\mathrm{K}$ was in the sample from Bahir Dar $(6516 \mathrm{mg} / \mathrm{kg})$ followed by Bure 
$(6156 \mathrm{mg} / \mathrm{kg})$, Fenote Selam $(6110 \mathrm{mg} / \mathrm{kg})$ and Debre Markos $(5482 \mathrm{mg} / \mathrm{kg})$. The order of $\mathrm{K}$ concentration by sample sites was Bahir Dar $>$ Bure $>$ Finote Selam $>$ Debre Markos. The concentration (mg/kg) of Mg from Bahir Dar was (643 mg/kg), Bure (554 mg/kg), Debre Markos $(551 \mathrm{mg} / \mathrm{kg})$ and Finote Selam $(546 \mathrm{mg} / \mathrm{kg})$. The levels of $\mathrm{Ca}$ in the samples were found as 684 , 445, 363 and $357 \mathrm{mg} / \mathrm{kg}$ from Debre Markos, Fenote Selam, Bure and Bahir Dar samples, respectively. Debre Markos sample was higher in $\mathrm{Ca}$ content than the samples from other three sites.

The major metals in barley grains showed variations among the sample sites. This might be due to the differences in the availability of the minerals in the soluble and usable forms, differences in the natural occurrence of these minerals in the areas, and differences in the degree of contamination of the soil by these metals. The use of different fertilizers, soil acidity and water for irrigation could also be the causes for the differences [34-36].

Table 6. Level of metals in $\mathrm{mg} / \mathrm{kg}$ in barley kolo, porridge, bread and injera from Bahir Dar, Bure, Fenote Selam, Debro Markos.

\begin{tabular}{|c|c|c|c|c|c|c|c|c|c|c|c|c|c|c|c|c|}
\hline \multirow[t]{3}{*}{ Metal } & \multicolumn{16}{|c|}{ Concentration $(\mathrm{mg} / \mathrm{kg})($ mean $\pm \mathrm{SD})$ of metals in samples from } \\
\hline & \multicolumn{4}{|c|}{ Bahier Dar } & \multicolumn{4}{|c|}{ Bure } & \multicolumn{4}{|c|}{ Fenote Selam } & \multicolumn{4}{|c|}{ Debre Markos } \\
\hline & $\mathrm{K}$ & $\mathrm{P}$ & $\mathrm{B}$ & I & $\mathrm{K}$ & $\mathrm{P}$ & $\mathrm{B}$ & I & $\mathrm{K}$ & $\mathrm{P}$ & $\mathrm{B}$ & $\mathrm{I}$ & $\mathrm{K}$ & $\mathrm{P}$ & $\mathrm{B}$ & $\mathrm{I}$ \\
\hline \multirow[t]{3}{*}{ K } & 4351 & 4735 & 686 & 4776 & 3839 & 4022 & 4241 & 428 & 4129 & 4148 & 4351 & 4158 & 460 & 4592 & 7762 & 4525 \\
\hline & $\exists$ & \pm & \pm & \pm & \pm & \pm & \pm & \pm & \pm & \pm & \pm & $=$ & \pm & \pm & I & \pm \\
\hline & 0. & 0.5 & 0.9 & 0.4 & 0.5 & 0. & 0.9 & 0.06 & 0.35 & 0.4 & 0. & 0. & 0. & 0.35 & 0. & 0.5 \\
\hline \multirow[t]{2}{*}{$\mathrm{Mg}$} & 640 & 767 & 744 & 763 & 46 & 655 & 649 & 68 & 602 & 659 & 614 & $\overline{6}$ & 54 & 653 & 6 & 684 \\
\hline & \pm 0.6 & \pm 0.8 & 0.3 & \pm 0.9 & \pm 0.6 & \pm 0.6 & \pm 0.4 & \pm 0.6 & \pm 0.3 & \pm 0.5 & \pm 0.6 & \pm 0.8 & \pm 0.3 & \pm 0.8 & \pm 0.8 & \pm 0.3 \\
\hline \multirow[t]{3}{*}{$\mathrm{Ca}$} & 395 & 18 & 430 & 891 & 598 & 658 & 622 & 727 & 437 & 397 & 547 & 5 & $40 s$ & 422 & 626 & 610 \\
\hline & \pm & & \pm & \pm & \pm & $=$ & & & $=$ & \pm & & & & \pm & & \\
\hline & 0.4 & 0.6 & 1.3 & 0.86 & 0.3 & 0.56 & 1.3 & 1.4 & 0.8 & 0.9 & 1 & 1. & 0.8 & 0.9 & 0.86 & 0.6 \\
\hline \multirow[t]{3}{*}{$\mathrm{Mn}$} & 7.34 & 8.91 & 9.29 & 9.74 & 7.52 & 9.00 & 8.75 & 10.5 & 7.14 & 8.4 & 8.5 & 0.0 & 0.0 & 8.3 & 9.5 & 11.7 \\
\hline & \pm & \pm & \pm & \pm & \pm & \pm & \pm & $=$ & $=$ & \pm & & & & \pm & & \\
\hline & 0.3 & 0.7 & 0.1 & 0.1 & 0.5 & 0.4 & 0.04 & 0.2 & 0.3 & 0.1 & 0.2 & U & 0 & 0.2 & 0.1 & 0.6 \\
\hline \multirow[t]{2}{*}{$\mathrm{Fe}$} & & 31 & 3 & 38 & 130 & 12 & 193 & 20 & 13 & 241 & 20 & 3 & 2 & 30 & 266 & 348 \\
\hline & \pm 0.2 & \pm 0.5 & 0.4 & \pm 0.3 & \pm 0.9 & \pm 0.5 & \pm 0.6 & 0.6 & \pm 0.5 & \pm 0.5 & \pm 0.5 & \pm 0.6 & \pm 0 & 0.5 & \pm 0.6 & $\pm 0 . S$ \\
\hline \multirow[t]{3}{*}{$\mathrm{Cu}$} & 1.58 & 4.78 & .74 & 2.86 & 1.61 & 2.47 & 2.45 & 2.6 & 2.21 & 2.7 & 2.4 & 6.27 & 4.10 & 5.25 & 4.51 & 5.82 \\
\hline & \pm & & \pm & \pm & \pm & \pm & & & \pm & & & & & & & \\
\hline & 0.08 & 0.09 & 0.11 & 0.06 & 0.04 & 0.03 & 0.03 & 0.05 & 0.04 & 0.03 & 0.1 & 0.06 & 0.08 & 0.05 & 0.12 & 0.09 \\
\hline \multirow[t]{2}{*}{$\mathrm{Zn}$} & 50 & 65 & 66 & 60 & 40 & 46 & 43 & 48 & 45 & 39 & 42 & 44 & 40 & 42 & 42 & 44 \\
\hline & \pm 0.5 & \pm 0.9 & 0.5 & \pm 0.5 & \pm 0.6 & \pm 0.7 & \pm 0.1 & \pm 0.7 & \pm 0.1 & \pm 0.8 & \pm 0.7 & \pm 0.5 & \pm 0.5 & 0.5 & \pm 0.6 & \pm 0. \\
\hline \multirow[t]{3}{*}{$\mathrm{Pb}$} & 1.71 & 2.16 & 5.32 & 3.13 & 1.59 & 1.88 & 2.46 & 2.33 & 2.08 & 1.7 & 3.02 & 2.87 & 2.2 & 2.43 & 2.63 & 2.69 \\
\hline & \pm & & \pm & \pm & \pm & \pm & \pm & \pm & $\exists$ & \pm & & \pm & & & & \pm \\
\hline & & 0 & .33 & 0 & 0.23 & 0 & 0.16 & 0.4 & 37 & 0.11 & 0 & 0. & 0.08 & .08 & 0.2 & 0.6 \\
\hline \multirow[t]{3}{*}{$\mathrm{Cd}$} & 3.31 & 3.81 & 4.08 & 3.21 & 2.93 & 2.79 & 3.76 & 4.25 & 2.98 & 3.09 & 2.76 & 2.4 & 3.15 & 2.46 & 1.6 & 1.86 \\
\hline & \pm & & \pm & \pm & 0 & \pm & \pm & \pm & \pm & & \pm & & & & & \\
\hline & .07 & 0.1 & .06 & 0.06 & 0.06 & 0.05 & 0.09 & 0.1 & 0.08 & 0.07 & 0.07 & 0.02 & 0.04 & 0.09 & 0.04 & 0.07 \\
\hline
\end{tabular}

$\mathrm{K}=$ Kolo, $\mathrm{P}=$ Porridge, $\mathrm{B}=$ Bread, $\mathrm{I}=$ Injera

\section{Levels of essential trace metals in barely grains}

It can be clearly seen from Tables 5 that $\mathrm{Fe}$ is the highest accumulated trace essential metal. This may be due to the nature of the soil produced either from fertilizer or animal and plant decomposition followed by $\mathrm{Zn}, \mathrm{Mn}$ and $\mathrm{Cu}$ with concentration ranges 42.8-56.8, 7.31-9.8 and $0.88-2.73 \mathrm{mg} / \mathrm{kg}$, respectively. The overall concentration of trace essential metals in barely grain was in the order $\mathrm{Fe}>\mathrm{Zn}>\mathrm{Mn}>\mathrm{Cu}$. The metals in the barley grains were in the same order in all the four sites. The lower concentration of trace minerals in the barley grain may be due to soil characteristics. There was a higher degree of variation in the level of $\mathrm{Fe}$ by sample sites. It was 
also at the highest level among the micro-essential metals. $\mathrm{Cu}$ exhibited small variation among the four sample sites as shown in Table 5 .

\section{Levels of toxic metals in barley grains}

The levels of $\mathrm{Pb}$ and $\mathrm{Cd}$ found in the present work are presented in Table 5. The amount of $\mathrm{Pb}$ and $\mathrm{Cd}$ determined in the barley grain from Bahir Dar was higher than from Bure, Fenote Selam and Debre Markos. The amount of $\mathrm{Pb}$ and $\mathrm{Cd}$ in the barley grain from Bahir Dar may be due to use of different fertilizers and pesticides containing $\mathrm{Pb}$ and $\mathrm{Cd}$ as an ingredient. Exposure to contamination during storage and transportation by cultivators could be the other causes for the higher values. The dietary exposure to $\mathrm{Cd}$ and $\mathrm{Pb}$ were estimated to be about $0.8 \mu \mathrm{g} / \mathrm{kg}$ of body weight daily and $0.02-3 \mu \mathrm{g} / \mathrm{kg}$ of body weight daily, respectively by the World Health Organization [4]. Accordingly the dietary intake of $\mathrm{Cd}$ and $\mathrm{Pb}$ should be less than $0.007 \mathrm{mg} / \mathrm{kg}$ of body weight, per week and $25 \mu \mathrm{g} / \mathrm{kg}$ of body weight daily, respectively [4].

\section{Concentration of metals in barley food samples}

The levels of metals in barley foods from the four sample sites were determined and are given in Table 6. There is a wide variation in the levels of metals in the four types of barley processed foods. Among the four types of barley foods kolo contains lowest amounts of all the metals. This is expected because during the preparation of kolo the barley grains are roasted which results in opening of the grains and subsequent loss of metals. In contrast to kolo, barley injera contains highest amounts of almost all the metals. This is because injera is baked at relatively lower temperature than the roasting of barley grains during kolo preparation. Barley porridge contains slightly lower amounts of metals than the injera but relatively higher levels of metals than the kolo and bread. Barley bread contains relatively higher levels of metals than the kolo but lower levels of metals than the injera and porridge.

There is no general trend in the levels of toxic metal $\mathrm{Cd}$ and $\mathrm{Pb}$ in the four types of barley processed foods. The highest amount of Cd $(4.66 \mathrm{mg} / \mathrm{kg})$ was obtained in the Bahir Dar injera while the lowest amount of $\mathrm{Cd}(1.6 \mathrm{mg} / \mathrm{kg})$ was found in the Debre Markos bread. The highest amount of $\mathrm{Pb}(5.32 \mathrm{mg} / \mathrm{kg})$ was observed in the Bahir Dar bread and lowest amount of $\mathrm{Pb}(1.50$ $\mathrm{mg} / \mathrm{kg}$ ) was found in the Bure kolo sample. The variation in the levels of $\mathrm{Cd}$ and $\mathrm{Pb}$ in the four types of barley processed food from four different areas may be due to use of different types and amounts of fertilizers and pesticides and differences in the nature and sources of irrigation water.

The variation in the levels of metals in the barley grain and its processed food depends up on the nature of individual metal, differences in the food processing, soil properties, environmental conditions and use of different fertilizers and pesticides. The variation in the levels of metal in the four types of barley foods may be also due to differences in the nature and sources of irrigation water and overall in the nature of soil and climatic conditions in the four different areas of barley cultivation.

It should be noted that there is wide variation in the mineral contents of barley grains collected from the four different sampling sites. There is also a wide differences in the preparation of four types of barley foods. The variation in the mineral contents of the barley grains from the four sampling sites is due to variations in the geographical locations and environmental conditions of the four sampling sites. While the variations in the mineral contents of the barley grains and the processed foods from the four sampling sites are due to variations in the geographical locations and environmental conditions of the four sampling sites as well as the variations in the processing of four types of barley foods. These two factors resulted in the random variations in mineral contents in the barley grains and its processed foods. 
Comparison of metal levels of present study with literature values

Several studies have been done on barley grain by different investigators in different countries. However, there is no detailed study conducted on the levels of metal contents in barley grains cultivated in Ethiopia. Therefore, the results of present study have been compared with the results reported from other countries in the literature as summarized in Table 7. The comparison shows that the levels of metals found in the present study are within the ranges of levels of metals reported in the literatures except $\mathrm{Mg}, \mathrm{Mn}$ and $\mathrm{Cu}$ which are lower than the literature values. The level of toxic metal $\mathrm{Cd}$ in this study is above the literature cited. However, there are variations in the levels of individual metal in the barley grain from different countries. The variations are expected due to differences in the soil properties, geographical locations, climatic conditions and agricultural practices in different countries.

Table 7. Comparison of macro-essential, micro-essential and non-essential metals concentration ( $\mathrm{mg} / \mathrm{kg}, \mathrm{dry}$ weight basis) in barley grain with reported values.

\begin{tabular}{|c|c|c|c|c|c|c|c|c|l|l|}
\hline $\mathrm{K}$ & $\mathrm{Mg}$ & $\mathrm{Ca}$ & $\mathrm{Mn}$ & $\mathrm{Fe}$ & $\mathrm{Cu}$ & $\mathrm{Zn}$ & $\mathrm{Pb}$ & $\mathrm{Cd}$ & Country & Reference \\
\hline 3050 & 1650 & 1300 & 13 & 87 & 7.6 & 175 & $\mathrm{NR}$ & $\mathrm{NR}$ & Egypt & {$[40]$} \\
\hline 8285 & 2686 & 891 & 23.9 & 937 & 8.12 & 33.7 & 1.45 & 0.29 & Pakistan & {$[41]$} \\
\hline $\mathrm{NR}$ & $\mathrm{NR}$ & $\mathrm{NR}$ & 38.7 & 1546 & 10.4 & 53 & 1.21 & 0.5 & Pakistan & {$[42]$} \\
\hline 3505 & 940 & 370 & 14.6 & 56.9 & 6.48 & 24.6 & $\mathrm{NR}$ & $\mathrm{NR}$ & Poland & {$[43]$} \\
\hline 1822 & 1810 & 1160 & 12.3 & 82.9 & 9.2 & 69 & $\mathrm{NR}$ & $\mathrm{NR}$ & Saudi Arabia & {$[44]$} \\
\hline 2700 & 650 & 200 & $\mathrm{NR}$ & 30 & $\mathrm{NR}$ & 21 & $\mathrm{NR}$ & $\mathrm{NR}$ & UK & {$[45]$} \\
\hline $\mathrm{NR}$ & $\mathrm{NR}$ & $\mathrm{NR}$ & 1.67 & 31.85 & 0.15 & 3.85 & 0.03 & $\mathrm{ND}$ & Ethiopia & {$[29]$} \\
\hline $\mathrm{NR}$ & $\mathrm{NR}$ & $\mathrm{NR}$ & $\mathrm{NR}$ & $\mathrm{NR}$ & 3.75 & 18.8 & 0.28 & 0.2 & Iran & {$[6]$} \\
\hline 6066 & 574 & 462 & 8.54 & 227 & 1.22 & 47.9 & 1.24 & 3.73 & Ethiopia & This study \\
\hline
\end{tabular}

$\mathrm{NR}=$ not reported, $\mathrm{ND}=$ not detected.

Analysis of variance (ANOVA)

One-way ANOVA was applied to assess the sources of variations observed in the level of metals as to whether it came from experimental procedure or due to heterogeneity among the samples. The results showed that there is a significant difference in the mean values of all the metals in the barley grain collected from four sampling area of Ethiopia. The differences are most likely due to heterogeneity among the samples because of the differences in the geographical locations and climatic conditions of the sampling sites.

\section{Pearson correlation of metals in barley grain}

Pearson correlation coefficients were employed to correlate the level one metal over the other metal. Pearson correlation coefficients revealed that there is negative, weak and/or moderate positive correlation between metals with each other. It was found that there was a strong positive correlation of $\mathrm{Cu}$ with $\mathrm{Zn}$ and $\mathrm{Pb}$ in the barley grain. The results are given in Table 8. These strong correlations may be due to their common natural sources as well as from similarity in their chemical properties.

\section{Daily intake of minerals from barley}

Metal concentrations in barely (this study), the amount that a person can get from $200 \mathrm{~g}$ barley per day, RDI and upper limit values of metals recommended by experts and agencies for a normal adult man is given in Table 9. 
Table 8. Pearson correlation of metals within barely grain samples.

\begin{tabular}{|c|c|c|c|c|c|c|c|c|c|}
\hline & $\mathrm{K}$ & $\mathrm{Mg}$ & $\mathrm{Ca}$ & $\mathrm{Mn}$ & $\mathrm{Fe}$ & $\mathrm{Cu}$ & $\mathrm{Zn}$ & $\mathrm{Pb}$ & $\mathrm{Cd}$ \\
\hline $\mathrm{K}$ & 1.0000 & & & & & & & & \\
\hline $\mathrm{Mg}$ & 0.6924 & 1.0000 & & & & & & & \\
\hline $\mathrm{Ca}$ & -0.9450 & -0.4635 & 1.0000 & & & & & & \\
\hline $\mathrm{Mn}$ & -0.7544 & -0.5262 & 0.8378 & 1.0000 & & & & & \\
\hline $\mathrm{Fe}$ & 0.2734 & -0.1281 & -0.2102 & 0.3575 & 1.0000 & & & & \\
\hline $\mathrm{Cu}$ & 0.6990 & 0.9472 & -0.4301 & -0.3240 & 0.1782 & 1.0000 & & & \\
\hline $\mathrm{Zn}$ & 0.6325 & 0.9448 & -0.3491 & -0.2666 & 0.1431 & 0.9959 & 1.0000 & & \\
\hline $\mathrm{Pb}$ & 0.6051 & 0.9501 & -0.3187 & -0.2613 & 0.1010 & 0.9911 & 0.9988 & 1.0000 & \\
\hline $\mathrm{Cd}$ & 0.9334 & 0.8984 & -0.8054 & -0.7598 & 0.0316 & 0.8510 & 0.8090 & 0.7971 & 1.0000 \\
\hline
\end{tabular}

Table 9. Metal concentrations in barley (this study), the amount that a person can get from $200 \mathrm{~g}$ barley per day, RDI and upper limit values of metals recommended by experts and agencies for a normal adult person $[4,46-48]$.

\begin{tabular}{|c|c|c|c|c|}
\hline Metal & $\begin{array}{c}\text { Concentration in barley } \\
(\mathrm{mg} / \mathrm{kg})\end{array}$ & $\begin{array}{c}\text { Amount of metal a } \\
\text { person can get from } \\
\text { 200 g barley }(\mathrm{mg})\end{array}$ & $\begin{array}{c}\text { Daily recommended } \\
\text { intake (RDI) } \\
(\mathrm{mg})\end{array}$ & $\begin{array}{c}\text { Maximum } \\
\text { permissible limit } \\
(\mathrm{mg} / \mathrm{day})\end{array}$ \\
\hline $\mathrm{K}$ & $5482-6516$ & $1096-1303$ & 4700 & $\mathrm{ND}$ \\
\hline $\mathrm{Mg}$ & $546-643$ & $109-127$ & $320-420$ & 750 \\
\hline $\mathrm{Ca}$ & $445-684$ & $89-137$ & $1000-1200$ & 2500 \\
\hline $\mathrm{Mn}$ & $7.31-9.8$ & $1.5-2$ & $1.8-2.3$ & 11 \\
\hline $\mathrm{Fe}$ & $127-439$ & $25-88$ & $10-15$ & 45 \\
\hline $\mathrm{Cu}$ & $0.88-1.86$ & $0.18-0.4$ & $0.9-2.3$ & 10 \\
\hline $\mathrm{Zn}$ & $42.8-56.8$ & $8.6-11$ & $10-15$ & 40 \\
\hline $\mathrm{Pb}$ & $0.39-2.73$ & $0.08-0.55$ & $0.02-3 \mu \mathrm{g} / \mathrm{kg} \mathrm{bw} / \mathrm{day}$ & $25 \mu \mathrm{g} / \mathrm{kg} \mathrm{bw} / \mathrm{day}$ \\
\hline $\mathrm{Cd}$ & $3.01-4.66$ & $0.6-0.9$ & $0.8 \mu \mathrm{gg} / \mathrm{kg} \mathrm{bw} / \mathrm{day}$ & $7 \mu \mathrm{g} / \mathrm{kg} \mathrm{bw} / \mathrm{week}$ \\
\hline
\end{tabular}

$\mathrm{bw}=$ body weight, $\mathrm{ND}=$ not established.

The amount of mineral intake by a person who consumes $200 \mathrm{~g}$ barley per day is shown in Table 9. The data shows that amount of major metals $(\mathrm{K}, \mathrm{Mg}$ and $\mathrm{Ca})$ a person can get from barley is lower than the daily recommended values. Therefore the person needs $\mathrm{K}, \mathrm{Mg}$ and $\mathrm{Ca}$ from other sources. The amount of trace metals $(\mathrm{Mn}$ and $\mathrm{Cu}$ ) that the man can get from barley is also below the required amount. Hence other diet is required for to get these metals up to the recommended values. The amount of Fe supply from barley for all the sample sites is very sufficient. The amount of $\mathrm{Zn}$ a person can get from barley is within the range of daily recommended intake from the Bahir Dar but not from other three sites. The values for $\mathrm{Pb}$ and $\mathrm{Cd}$ are above the allowable limits. The man must not consume large quantity of foods from barley regularly.

\section{CONCLUSION}

The levels of metals in barley grain and four types of barley processed foods were determined. The order of metals contents in the raw grain and processed foods were different from each other. This is due to the differences in food processing practices. Barley grain from the selected sites accumulated relatively higher levels of $\mathrm{K}(5482-6516 \mathrm{mg} / \mathrm{kg})$ and $\mathrm{Fe}(128-439 \mathrm{mg} / \mathrm{kg})$ among major and trace metals, respectively, and lower level of $\mathrm{Cu}(0.88-1.86 \mathrm{mg} / \mathrm{kg})$. The ANOVA result at $95 \%$ confidence level suggested significant differences in the level of metals among the barley grain samples collected from the four different regions of Ethiopia. These differences may be due to the difference in the soil chemical composition and environmental conditions which control the degree of mineral absorption by barley plants. The barley grain and its processed foods are good 
sources of essential metals. However, the $\mathrm{Pb}$ and $\mathrm{Cd}$ contents in the barley grains are above the allowable limits. Therefore people should not consume large quantity of foods from barley regularly.

\section{ACKNOWLEDGMENT}

The authors express their gratitude to the Department of Chemistry, Addis Ababa University, Ethiopia for providing the laboratory facilities.

\section{REFERENCES}

1. Chimdi, A.; Gebrekidan, H.; Kibret, K.; Tadesse, A. Response of barley to liming of acid soils collected from different land use systems of Western Oromo, Ethiopia. J. Biodivers. Environ. Sci. 2012, 2, 37-49.

2. Kaso, T.; Guben, G. Review of barley value chain management in Ethiopia. J. Biol. Agric. Healthcare 2015, 5, 84-97.

3. Woldemariam, F.; Mohammed, A.; Teferra, T.F.; Gebremedhin, H. Optimization of amaranths-teff-barley flour blending ratios for better nutritional and sensory acceptability of injera. Cogent Food Agric. 2019, 5, 1-15, Article no. 1565079.

4. FAO/WHO (2011). Joint FAO/WHO food standards programme codex committee on contaminants in foods, working document for information and use in discussions related to contaminants and toxins in the GSCTFF, Fifth Session The Hague, The Netherlands, 21-25 March 2011. Available at: http://faostat.fao.org/default.aspx. Accessed 14 April, 2015.

5. Gubrelay, U.; Agnihotri, R.K.; Singh, G.; Kaur, R.; Sharma, R. Effect of heavy metal Cd on some physiological and biochemical parameters of barley (Hordeum vulgare L.). Int. J. Agric. Crop Sci. 2013, 5, 2743-2751.

6. Sadeghi, N.; Oveisi, M.R.; Reza, O.M.; Jannat, B.; Hjimahmoodi, M.; Malayeri, N.; Behzad, M. Assessment of some heavy metals concentration and antioxidant activity in barley grain cultivars and their malts from Iran. J. Agric. Chem. Environ. 2016, 5, 121-131.

7. Mekonnen, L.; Woldekiros, B. Response of food barley (Hordeum vulgare L.) to various levels of P fertilizer. Int. J. Res. Agric. Forestry 2018, 5, 21-26.

8. Rashid, S.; Abate, G.T.; Lemma, S.; Warner, J.; Kasa, L.; Minot, N. Barley value chain in Ethiopia. International Food Policy Research Institute, 2015. DOI: 10.13140/RG. 2.1.3670.8724.

9. Terefe, D.; Desalegn, T.; Ashagre, H. Effect of nitrogen fertilizer levels on grain yield and quality of malt barley (Hordeum vulgare L.) varieties at Wolmera district, central highland of Ethiopia. Int. J. Res. Stud. Agric. Sci. 2018, 4, 29-43.

10. Zhou, M.X. Barley production and consumption. Tasmanian Institute of Agricultural Research 2010. DOI: 10.1007/978-3-642-01279-2_1.

11. Idehen, E.; Tang, Y.; Sang, S. Bioactive phytochemicals in barley. J. Food Drug Anal. 2017, $25,148-161$.

12. Mohammed, J.; Seleshi, S.; Nega, F.; Lee, M. Revisit to Ethiopian traditional barley based food. J. Ethnic Foods 2016, 3, 135-141.

13. Abeshu, Y.; Abrha, E. Evaluation of proximate and mineral composition profile for different food barley varieties grown in central highlands of Ethiopia. World J. Food Sci. Technol. 2017, 1, 97-100.

14. Das, M.; Kaur, S. Status of barley as a dietary component for human. Res. Rev.: J. Food Dairy Technol. 2016, S1, 25-30.

15. Andersson, A.A.M.; Elfverson, C.; Andersson, R.; Regnér, S.; Åman, P. Chemical and physical characteristics of different barley samples. J. Sci. Food Agric. 1999, 79, 979-986. 
16. Metayer, J.P. Study of variability in French cereals. Animal Feed Sci. Technol. 1993, 43, 87-108.

17. Rodehutscord, M.; Rückert, C.; Maurer, H.P.; Schenkel, H.; Schipprack, W.; Knudsen, K.E.B.; Schollenberger, M.; Laux, M.; Eklund, M.; Siegert, W.; Mosenthin, R. Variation in chemical composition and physical characteristics of cereal grains from different genotypes. Arch. Animal Nutr. 2016, 70, 87-107.

18. Hashash, M.; El-yed, M.; Abdel-hady, A.; Hady, H.; Moris, E. Nutritional potential, mineral composition and antioxidant activity squash (Cucurbita pepo) fruits grown in Egypt. Eur. $J$. Biomed. Pharm. Sci. 2017, 4, 05-12.

19. Hajeb, P.; Sloth, J. J.; Shakibazadesh, S.; Mahyudin, N. A.; Afsah-Hejri, L. Toxic elements in food: Occurrence, binding, and reduction approaches. Compr. Rev. Food Sci. Food Saf. 2014, $13,457-472$.

20. Soetan, K.; Olaiya, C.; Oyewele, O. 2010. The importance of mineral elements for humans, domestic animals and plants: A review. Afr. J. Food Sci. 2010, 4, 200-222.

21. Atlabachew, M.; Chandravanshi, B.S. Levels of major, minor and trace elements in commercially available enset (Ensete ventricosum (Welw.) Cheesman) food products (Kocho and Bulla) in Ethiopia. J. Food Compos. Anal. 2008, 21, 545-552.

22. Debebe, A.; Chandravanshi, B.S.; Wondimu, T. Metallic nutrients in enset (Ensete ventricosum) corm cultivated in Wolliso and Wolkite towns in Ethiopia. SINET: Ethiop. J. Sci. 2012, 35, 71-80.

23. Aregahegn, A.; Chandravanshi, B.S.; Atlabachew, M. Levels of major, minor and toxic metals in tubers and flour of Dioscorea abyssinica grown in Ethiopia. Afr. J. Food, Agric. Nutr. Dev. (AJFAND) 2013, 13, 7870-7887.

24. Akalu, Z.K.; Chandravanshi, B.S. Levels of essential and non-essential elements in raw and processed Lupinus albus L. (White lupin, Gibto) cultivated in Ethiopia. Afr. J. Food Agric. Nutr. Dev. (AJFAND) 2014, 14, 2015-2035.

25. Ayele, E.; Urga, K.; Chandravanshi, B.S. Effect of cooking temperature on mineral content and antinutritional factors of yam and taro grown in southern Ethiopia. Int. J. Food Eng. 2015, $11,371-382$.

26. Abebe, A.; Chandravanshi, B.S. Levels of essential and non-essential metals in the raw seeds and processed food (roasted seeds and bread) of maize/corn (Zea mays L.) cultivated in selected areas of Ethiopia. Bull. Chem. Soc. Ethiop. 2017, 31, 185-199.

27. Abebe, A.; Chandravanshi, B.S.; Debebe, A. Assessment of essential and non-essential metals in popcorn and cornflake commercially available in Ethiopia. Chem. Int. 2017, 3, 268-276.

28. Tegegne, B.; Chandravanshi, B.S.; Zewge, F. Levels of selected metals in commercially available rice in Ethiopia. Int. Food Res. J. 2017, 24, 711-719.

29. Tegegne, W.A. Assessment of some heavy metals concentration in selected cereals collected from local markets of Ambo City, Ethiopia. J. Cereals Oilseeds 2015, 6, 8-13.

30. Mehari, A.K.; Gebremedhin, S.; Ayele, B. Effects of Bahir Dar textile factory effluents on the water quality of the head waters of Blue Nile River, Ethiopia. Int. J. Anal. Chem. 2015, 2015, Article ID 905247.

31. Tadesse, E.; Getaneh, G.; Assaye, M. Prevalence of bovine trypanosomosis in Bure and Womberma Districts of West Gojjam Zone, North West Ethiopia. Acta Parasitologica Globalis 2015, 6, 164-173.

32. Abate, A.; Birhan, W.; Fola, A.A. Association of anemia and renal function test among diabetes mellitus patients attending Fenote Selam Hospital, West Gojam, Northwest Ethiopia: A cross sectional study. BMC Hematol. 2013, 13, Article no. 6. DOI: 10.1186/2052-183913-6.

33. Berhanu, M.A.; Akola, J. Environmental perspective of urban agriculture in Debre Markos Town, Amhara Regional State, Ethiopia. J. Environ. Earth Sci. 2014, 4, 13-20. 
34. Abraha, A.; Uhlen, A.K.; Abay, F.; Sahlstrøm, S.; Bjørnstad, Å. Roasted barely foods processing and varietal differences affecting kolo and tihni. Traditional grain products in northern Ethiopia. Cereal Foods World 2013, 58, 71-79.

35. Al-Mussali, M.S.; Al-Gahri, M.A. Nutritive value of commonly consumed bread in Yemen. J. Chem. 2009, 6, 437-444.

36. Taleuzzaman, M. Limit of blank (LOB), limit of detection (LOD), and limit of quantification (LOQ). Org. Med. Chem. Int. J. 2018, 7, Article no. 555722.

37. Takáč, P.; Szabová, T.; Kozáková, L.; Benková, M. Heavy metals and their bioavailability from soils in the long-term polluted Central Spiš region of SR. Plant Soil Environ. 2009, 55, $167-172$.

38. Ogoko, E.C. Accumulation of heavy metal in soil and their transfer to leafy vegetables with phytoremediation potential. Am. J. Chem. 2015, 5, 125-131.

39. Belayneh, T.; Atnafu, Z.; Madhusudhan, A. Determinations of the level of essential and nonessential metals in rice and soil samples. Int. J. Modern Chem. Appl. Sci. 2015, 2, 65-72.

40. Youssef, M.K.E.; El-Fishawy, F.A.E.-K.; Ramadan, E.-S.A.E.N.; El-Rahman, A.M.A. Nutritional assessment of barley, talbina and their germinated products. Front. Sci. 2013, 3, 56-65.

41. Shar, G.Q.; Kazi, T.G.; Shar, L.A.; Jamali, M.K.; Afridi, H.I.; Arain, M.B. Multielement analysis of Pakistani barley (Hordeum vulgare L.) varieties by flame atomic absorption spectrometry. J. Res. (Sci.) 2007, 18, 69-77.

42. Shar, G.Q.; Kazi, T.G.; Jatoi, W.B.; Makhija, P.M.; Sahito, S.B.; Shar, A.H.; Soomro, F.M. Determination of heavy metals in eight barley cultivars collected from Wheat Research Station Tandojam, Sindh, Pakistan. Pak. J. Anal. Environ. Chem. 2013, 14, 47-53.

43. Wozniak, A.; Soroka, M.; Stępniowska, A.; Makarski, B. Chemical composition of spring barley (Hordeum vulgare L.) grain cultivated in various tillage systems. J. Elementol. 2014, 2, 597-606.

44. Ghafoor, K.; Al-Juhaimi, F.; Ozcan, M.M.; Jaharul, M.H.A. Some nutritional characteristics and mineral contents in barley (Hordeum vulgare L.) seeds cultivated under salt stress. Qual. Assur. Saf. Crops Foods 2015, 7, 363-368.

45. McKevith, B. Nutritional aspects of cereals. Nutr. Bull. 2004, 29, 111-142.

46. National Research Council. Recommended dietary allowances, 10th ed., Food and Nutrition Board, National Academy Press: Washington DC; 1989.

47. Food and Nutrition Board. Institute of Medicine, National Academies, USA; 1997,

48. NebGuide. Upper safe levels of intake for adults: Vitamins and minerals, 2009. Retrieved on February 13, 2015 from Website: http://www.ianrpubs. unl.edu/pages/publicationD.jsp?publicationId=295. 